\title{
Risperidone Effectiveness with Attentional in Schizophrenic Patients
}

\author{
Lenni C. Sihite, Mustafa Mahmud Amin, Bahagia Loebis \\ Faculty of Medicine, University of Sumatera Utara, Jalan dr. Mansur No 5 Medan 20155, Sumatera \\ Utara \\ * E-mail of the corresponding author: lenni_cs@ymail.com
}

\begin{abstract}
Risperidone can be found in studies of schizophrenic patients which is more effective than haloperidol in reducing the total score of positive symptoms and negative symptoms in a dose of 4-8 $\mathrm{mg}$ per day. The objective of this study is to determine the benefits of risperidone on attentional improvements, get a picture and information about the use of STROOPTES to assess the improvement of attention. This study is an experimental study, in the form of open label clinical trial one group pretest-posttest design. to assess the effectiveness of risperidone on attention in schizophrenic patients. The result showed that the frequency of males is more common that $20(66.7 \%)$, SMA $23(76.7 \%), 25-34$ age group of 15 people $(50 \%)$. From this study it was found that risperidone relationship with attentional values in Table 2 shows the mean value of the first Test Strooptest before given risperidone 18.3 (SD 2.3) and mean Strooptest Test I after administration of risperidone $4 \mathrm{mg}$ IV at week 17.8 (SD 2.4). From the statistical test using the dependent $t$ test of the obtained mean value of $p=0.007 \mathrm{p}>$ 0.05 it indicates no significant differences before the given risperidone on Test I and after administration of risperidone in Test I. Mean values obtained from research Strooptest Test II before being given risperidone 39.5 (SD 2.5) and mean Strooptest Test II after administration of risperidone $4 \mathrm{mg}$ IV at week 38.5 (SD 2.9). From the statistical test using the dependent t-test $\mathrm{p}$-value $=0.0001$ obtained by means of $\mathrm{P}<0.05$ it indicates no significant differences after administration of risperidone in the second week of the fourth Test. This indicates significant differences were assessed by means of measuring strooptest. Conclusion is that the results indicated after a four-week study with administration of $4 \mathrm{mg}$ risperidone experienced a significant change in the value of strooptest test I and test II.
\end{abstract}

Keywords: attention, risperidone, schizophrenia

\section{Introduction}

Hill et al in 2004 demonstrated in patients before and after 6 weeks of treatment with risperidone administration, an increase in visual perception but failure to improve with a reduction in motor attention ${ }^{1}$ Research Barkie, et al on the effect of risperidone on cognitive function in patients with schizophrenia by taking a sample of 50 people who came in the outpatient clinic, subjects received risperidone at a dose of 3-4 mg once daily in the morning, it turns out after 3 months of treatment with risperidone did not found the existence of changes significantly attention. ${ }^{2}$

From research Rossi and colleagues showed risperidone has a positive effect in assessing attention to stimuli and verbal working memory. Preliminary evidence also suggests an increase in attention to visual stimuli. In addition there is still controversy regarding the relationship between psychopathology and improvement in cognitive function and cognitive areas are particularly affected by the drug. The purpose of this study was to evaluate the effect of risperidone on information processing and attention in schizophrenia patients after 8 weeks of treatment with an average daily dose of $7.3 \mathrm{mg}(+-4.0)$. At the end of the study found no significant change in the patient's cognitive impairment, although significant changes were found klinis. ${ }^{3}$

Attentional impairment is one of the symptoms of cognitive impairment that may lead to poor social relationships and interference in the work function can be found in schizophrenic patients in the General Services Agency Regional Mental Hospital in North Sumatra Province, the authors are interested to see the connection with the administration of risperidone attention value in schizophrenic patients. ${ }^{4}$

\section{Subject and Methods}

This study was approved by the Research Ethics Committee of Medical Faculty University of Sumatera Utara. This research is an experimental study, in the form of open label clinical trial one group pretest-posttest design. The aim is to assess the effectiveness of risperidone on attention in schizophrenic patients. These study was performed in Mental Hospital of Province of North Sumatera, on the regulation of Medical Faculty of University of North Sumatera, from Februari untill May 2011. The criteria inclusion was 15-55 years old, first 
met with inspectors, cooperative, schizophrenics who fit the criteria PPDGJ III, acute phase, can read and recognize numbers, willing as research subjects.

Exclusion criteria: patients with comorbid schizophrenia and other psychiatric disorders or general medical illness, substance usage, pregnant or nursing mothers, were using antipsychotic drugs and other drugs besides risperidone, color blindness, rowdy restless.

\subsection{Implementation}

All patients who met the inclusion criteria skizoprenia fill out a written consent after receiving a detailed explanation and clear to participate in the study.

Subjects will undergo a color blind test. At the first visit (baseline), PANSS assessment and strooptest I and II after the patients were given risperidone $2 \mathrm{mg}$ per day. The second week of re appraisal PANSS scores and strooptest I and II and a dose of $2 \mathrm{mg}$ per day still. In the third week dose of risperidone was increased to $3 \mathrm{mg}$ per day was assessed score of the PANSS and strooptes I and II. Week four doses of risperidonewas increased to $4 \mathrm{mg}$, PANSS scores and strooptest I and II assessed. Patients were evaluated for 4 weeks and compared to the value strooptest I and II before and after administration of risperidone.

\subsection{Statistical Analysis}

Univariat analysis was performed to describe each variable and was described by frequency table. The statistical analysis were assessed using SPSS 15.5. A significant level was considered as 5\%.

\section{Result}

A total of 30 patients with paranoid schizophrenic outpatient and inpatient BLUD Mental Hospital of North Sumatra Province, received treatment with risperidone were selected using consecutive sampling included in this study. The result showed that the frequency of males is more common that 20 (66.7\%), SMA 23 (76.7\%), 25-34 age group of 15 people $(50 \%)$.

\section{Discussion}

From this study it was found that risperidone relationship with attentional values in Table 2 shows the mean value of the first Test Strooptest before given risperidone 18.3 (SD 2.3) and mean Strooptest Test I after administration of risperidone $4 \mathrm{mg}$ IV at week 17.8 (SD 2.4). From the statistical test using the dependent t test of the obtained mean value of $\mathrm{p}=0.007 \mathrm{p}<0.05$ it indicates no significant differences before the given risperidone on Test I and after administration of risperidone in Test I.

Mean values obtained from research Strooptest Test II before being given risperidone 39.5 (SD 2.5) and mean Strooptest Test II after administration of risperidone $4 \mathrm{mg}$ IV at week 38.5 (SD 2.9). From the statistical test using the dependent $\mathrm{t}$-test $\mathrm{p}$-value $=0.0001$ obtained by means of $\mathrm{P}<0.05$ it indicates no significant differences after administration of risperidone in the second week of the fourth test. This indicates significant differences were assessed by means of measuring strooptest.

From research Rossi and colleagues showed risperidone has a positive effect in assessing attention to stimuli and verbal working memory. Preliminary evidence also suggests an increase in attention to visual stimuli.

\section{Conclusion}

Results are shown after a four-week study with administration of $4 \mathrm{mg}$ risperidone experienced a significant change in the value ofstrooptest test I and test II.

Met with neurocognitive symptoms in schizophrenic patients is necessary for the examination of cognitive symptoms of schizophrenia with one test of attention in patients with inpatient or outpatient care to avoid poor social and occupational functioning in schizophrenic patients.

\section{References}

1. Roback HW, Welch L. Psychological Testing in Psychiatri. Ebert MH, Loosen P, Nurcombe B eds. Current Diagnosis \& Treatment in Psychiatry. Singapore: McGraw Hill Book Co; 2000. h. 137-54

2. Amando, Bourdel, Daban C, Poirier MF, Loo H, Bouhours P. Preattennional process and disorganization an schizophrenia: Influence of a 6-week riperidone treatment. Dalam. Progress in Neuro-Psychopharmacology \& Biological Psychiatry 33, 2009: h. 1107-12 
3. Barkie J, Filakovie P, Radanovic L, Koic O, Laufer D, Pozgain I at al. The Influence of Risperidone on Cognitive Function in Schizofrenia.Collantropol.27 suppl 111-118.

4. Hong KS, Kim JG, Koh HJ et al. Dalam: Effects of risperidone on information processing and attention in first-episiode schizophrenia. Schizophrenia Research 53 (2002) 7-16

\section{First A. Lenni C. Sihite}

Medical Doctor (MD), Resident in University of Sumatera Utara.

\section{Second A. Mustafa Mahmud Amin}

Medical Doctor (MD), Psychiatrist, M. Sc

\section{Third A. Bahagia Loebis}

Medical Doctor (MD), Psychiatrist and Consultant in Biology. 
The IISTE is a pioneer in the Open-Access hosting service and academic event management. The aim of the firm is Accelerating Global Knowledge Sharing.

More information about the firm can be found on the homepage:

http://www.iiste.org

\section{CALL FOR JOURNAL PAPERS}

There are more than 30 peer-reviewed academic journals hosted under the hosting platform.

Prospective authors of journals can find the submission instruction on the following page: http://www.iiste.org/journals/ All the journals articles are available online to the readers all over the world without financial, legal, or technical barriers other than those inseparable from gaining access to the internet itself. Paper version of the journals is also available upon request of readers and authors.

\section{MORE RESOURCES}

Book publication information: http://www.iiste.org/book/

\section{IISTE Knowledge Sharing Partners}

EBSCO, Index Copernicus, Ulrich's Periodicals Directory, JournalTOCS, PKP Open Archives Harvester, Bielefeld Academic Search Engine, Elektronische Zeitschriftenbibliothek EZB, Open J-Gate, OCLC WorldCat, Universe Digtial Library, NewJour, Google Scholar

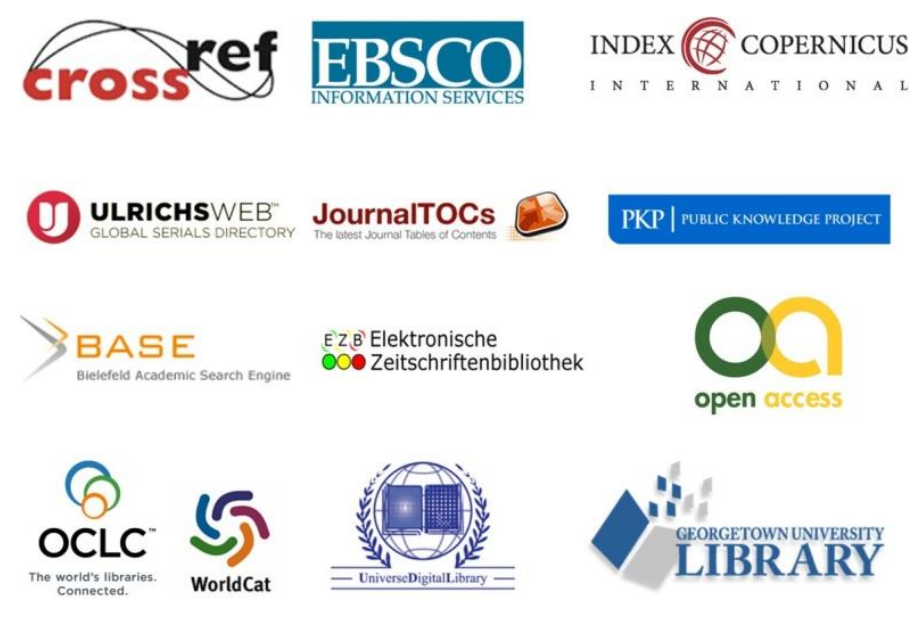

